\title{
Critical thinking of field dependent student's in problem solving
}

\author{
Dian Septi Nur Afifah ${ }^{1} *$, Ria Lestari Ningrum ${ }^{2}$ \\ ${ }^{1,2}$ STKIP PGRI Tulungagung, Jl. Mayor Sujadi Timur No. 7 Tulungagung, Indonesia
}

\begin{tabular}{l}
\hline A R T I C L E I N F O \\
Original Article \\
doi: $10.18860 /$ ijtlm.vli1.5465 \\
\hline Keywords: \\
Critical Thinking, Problem \\
Solving, Field Dependent
\end{tabular}

\begin{abstract}
A B S T R A C T
The purpose of this research is to describe the characteristics of the critical thinking of field-dependent cognitive style students in problem-solving. This research is qualitative research. Research subjects are students who have field-dependent cognitive style in class VIII SMP Negeri 1 Boyolangu, Indonesia. Data collection is GEFT test, math problem test, and interview. The results showed that strong field dependent students in mathematics problem solving aren't good at understanding the problem. At the implementing stage, the solution stage according to the previous plan. The problem-solving plan depends on the formulation of the problem that students found, students are less precise in carrying out the problem-solving. Students do not check again the answer. Critical thinking of weak field dependent students is not good in understanding the problem, and information in the problem is quite good. At the making solution plan stage, students do not write down what is known and asked and less able to express a solution plan clearly and logically with the problem. At the implementing stage, the solution plan is by the previous plan. The problemsolving plan depends on the problem formulation of the problem that students found, so students are less precise in carrying out the problem-solving. Students do not check again the answers.
\end{abstract}

(C) 2018 IJTLM. All rights reserved.

*Corresponding author.

E-mail: dian.septi@ stkippgritulungagung.ac.id

How to cite: Afifah, D. S. N., \& Ningrum, L. R. (2018). Critical thinking of field dependent student's in problem solving. International Journal on Teaching and Learning Mathematics, 1(1), 31-38.

\section{INTRODUCTION}

One of the purposes in mathematics learning is students ability in problem-solving. In solving mathematics problem high-level thinking is needed, one of which is critical thinking. Ennis (1995) said that critical thinking is logical and reasonable thinking that is focused on deciding what is believed and done. Critical thinking is the students' ability to analyze and evaluate the information to decide whether the information can be trusted so it used to draw valid conclusions (Albitz, 2007; Facione, 2011; Facione \& Facione, 1996; Fithriyah, Sa'dijah, \& Sisworo, 2016; Halpern, 1998; Huang \& Yeh, 2017; Siew \& Mapeala, 2016). Rasiman (2015) said that critical thinking is a mental process that is organized and plays a role in the decisionmaking process to solve the problem. So critical thinking includes analyzing activities and data interpreting at scientific inquiry activities. Therefore, critical thinking can help someone in deciding what is trusted or that will be done logically based on fact by the situation that faced.

However, based on the result of the personal interview with several mathematics teachers, students critical thinking skills are very low. It is known when students are given incomplete questions and the majority of students continue to answers it so the final answer is automatically 
wrong. In addition, based on the observation result at school, teachers still rarely provide training in non-routine questions that can train students critical thinking.

For this reason, it needs to take the practice of non-routine questions to train students critical thinking continuously through learning mathematics. Because critical thinking can be a habit that students do in their lives. Problem-solving is the "action-end" or implementation component of the overall critical thinking proses in other words (Hendricson et al., 2006)

Critical thinking is an integrated part of the concept of the creativity and the programs that are directed to develop critical thinking must focus on cognitive style among other factors (Emir, 2013). Cognitive style is someone's way to process, save, or use the information to respond to a task or the various type of environment. Witkin et al. divide cognitive style in two cognitive styles, Field Dependent (FD) - Field Independent (FI) (Afifah, 2011). In this research, we focus to observe students who have field-dependent cognitive style.

Some previous researches about critical thinking has been done (Hendricson et al., 2006; Huang, Ricci, \& Mnatsakanian, 2016; Hudha \& Batlolona, 2017; Maandig, Lomibao, \& Luna, 2017; Paradesa, 2016). Hendricson et al. (2006) created the critical thinking component. Furthermore, Paradesa (2016) showed that the ability of critical thinking college students through the constructivist approach in financial mathematics courses is low and including fewer categories. Huang, Ricci, and Mnatsakanian (2016) discussed students'patways in developing critical thinking and metacognition. Hudha \& Batlolona (2017) investigated students' critical thinking skills taught by using inquiry-discovery. Maandig, Lomibao, and Luna (2017) identified the significant impact of structured content reading instruction and direct instruction on students' mathematics achievement, reading comprehension, and critical thinking. Those studies did not examine students'critical thinking based on cognitive style. In fact, cognitive style may be an key factor in determine students's existing knowledge and learning performance (Chinien \& Boutin, 1993; Mayer \& Massa, 2003; Riding, \& Sadler-Smith, 1997; Sadler-Smith, \& Badger, 1998; Sadler-Smith \& Riding, 1999; Tascón, Boccia, Piccardi, \& Cimadevilla, 2017).

For that, research needs to be done about students critical thinking in solving the problem in terms of cognitive style. Hence, the purposes in this research are to (1) know the characteristic of students critical thinking in solving the problem that has strong field-dependent cognitive style and (2) know the characteristic of students critical thinking in solving the problem that has weak field-dependent cognitive style.

\section{METHOD}

This study used qualitative research. The study was conducted in class VIII at SMP Negeri 1 Boyolangu. Subjects who were given the Group Embedded Figures Test (GEFT). GEFT test was then selected by students who had a field-dependent cognitive style in the category of strong and weak. Data collection techniques were tests of mathematical problems, and interviews. Mathematical test questions in the form of essays consisting of 2 questions. In this study, we analysed data using 3 steps, namely reducing data, presenting data, and drawing conclusion. We reduced the data in form of cognitive style test result using the GEFT instrument, the result of mathematical problem test in the form of essay questions, interview transcripts between researchers and research subjects about students' critical thinking and documentation. Credibility test in this research used time triangulation. Furthermore, we presented the data which includes the classification of data by licensing sequential data sets so that it can be used to conclude the data and discussed based on students' critical thinking which 
depends on the area being improved. The last step is making the conclusions on students' critical thinking for each question with each students' cognitive style in problem-solving.

\section{RESULTS AND DISCUSSION}

This research included GEFT test, making an instrument, data analysis until making the conclusions. The plot in this study starts from select the research subject, doing a GEFT test, give a circle problem mathematics test, then selecting a research plot subject.

Figure 1. Weak field dependent student (WFD) problem test answer number 1

$$
\begin{aligned}
& \text { Rectangle }=50 \mathrm{~cm} \times 40 \mathrm{~cm} \\
& =2.000 \mathrm{~cm}^{2} \\
& \begin{aligned}
\text { Circle } & =3.14 \times 5 \times 5 \\
& =7850
\end{aligned} \\
& \begin{aligned}
\mathrm{L} \quad= & 7850-2000 \\
= & 5850
\end{aligned}
\end{aligned}
$$

The answer given by Weak Field Dependent (WFD) student shows that the student did not write down the formulation of the problem and the information that they have as a step in using a strategy planned. However, subject was not careful in calculating so the value obtained is wrong, even though the concept is right, that is searching the area of the circle by means of $\pi$.r.r. From the next strategy, subject made mistake in understanding the formulation of the problem that given. It can be seen from the answer, subject said "L" maybe according subject, the purpose of this problem to find the remaining area so the final answer from subject is incorrect in number 1 .

After the subject answers the problem, the researcher (R) did interviews to WFD. Following the extract of interviews that supports the answer given by the students.

$R \quad:$ "do you know the formulation of the problem?"

WFD : "yes ma'am, that is looking for the area of remaining zinc"

$R \quad:$ "fine, then how are you going to solve the problem?"

WFD : "rectangle catches should be reduced by the wide circle of mom, but when I do the calculation, the circle is a larger mom. So I just subtract the vast area of a rectangle with circles"

$R \quad:$ "try to re-checking your answer, is that correct?"

WFD : "briefly mom, oh yes, I'm wrong to count them."

From the interview, it can be seen subject find the formula problem that exists on the question, but the outline of the issues that have been discovered by the subject is less precise. The error analysis in finding this formulation will affect the strategies that will be used subject in solving the problem. At the next stage, the subject saying that the subject was wrong in doing the calculations so that he gets the final answer which is less precise. From here it looks that subject less conscientious in doing the calculation strategies, that affecting the final answer of the problem. 
Based on the result of the subject answer, the subject solved the problem by doing a settlement plan. By finding new information obtained from calculations after getting preliminary information on the given problem, the subject did strategy in solving the problem uses the new information subject obtained. However, because the subject was wrong in understanding the formula problem, so the subject used the concept is less in given problemsolving.

The subject didn't write down the answer or strategies used in solving problems in that number. When the subject read the problem in number 2 , seen that the subject understands the problem. So in number 2, the researchers cannot conclude about the things that have known or the things that make subject didn't answer the problem.

From that figure researchers interview the subject. This is the extract of interviews that researchers do for deepening the problem that exists when subject doing number 2. Also, knowing how far subject understand that question.

$R \quad:$ "why didn't you do number 2?"

WFD : "the time is out mom, so I can't answer that number 2"

$R \quad:$ "now try to explain what do you known from that question"

WFD : "there is a park that looks like a circle mom, with diameter 21 and 14."

$R \quad:$ "yes, then what asked in that question?"

WFD : "remaining area from that park mom"

From the extract of interviews, it looks that the subject knows the information in the question, but the subject wrong in understanding the formula in that question. In those cases, the subject will do an inaccurate strategy to solve the problem. Based on the answer and interview that the researchers does, it looks that the subject knows and understands the information that the subject obtained from the problem, but subject inaccurate explaining about the problem formula that given.

From the whole answer and interview that has been done by the researchers, can be concluded that subject whom WFD tend wrong in finishing the problem formula and sometimes subject can't find the problem formula or the aim from a problem that has given. But in finding the information subject right. Subject tended incorrect determine the problem formula that has an impact on the strategy that will be used by the subject in solving the problem. So, the subject's final answer is incorrect. Sometimes, the subject not careful doing the calculation in solving the problem. This is influence the subject's answer in solving the problem.

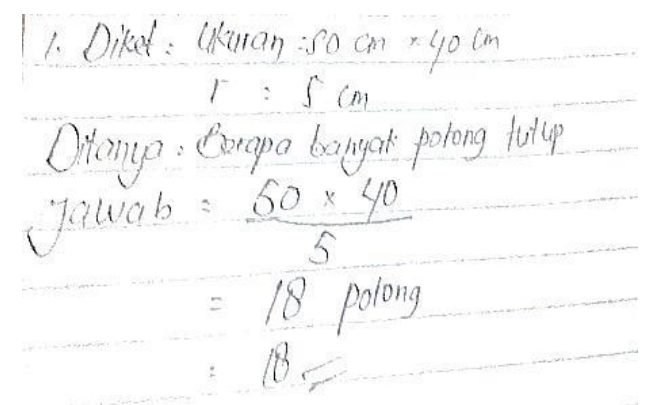

Figure 2. Strong field dependent student (SFD) problem test answer number 1

Known: size $=50 \mathrm{~cm} \mathrm{x} 40 \mathrm{~cm}$

$\mathrm{r}=5 \mathrm{~cm}$ 


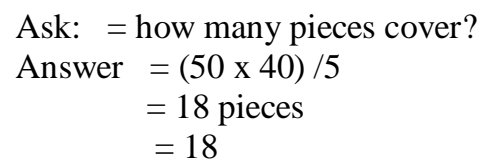

From answer that strong field dependent (SFD) student give it look that student know the formula and information about the problem, write the information well and write the problem formula correctly. But, a strategy that use in solving the problem incorrectly, the student only uses information that exists directly without processing it, so the final answer from the subject incorrect in solving the problem. After student answered problem that has given, researchers interviewed student. This is the fragment interview that supports the student's answer.

$R \quad:$ "yes, then from the information that you find, how is your strategy to solve the first problem?"

SFD : "by multiplying the size of length and width of the rectangle, then divided by the closed fingers mom"

$R \quad:$ "why did you use that strategy?"

SFD : "we will find the number of caps mom, and from the information that already exists, so we can do by divided with circle fingers is known above."

From that interview, so can conclude that the subject incorrect explains the strategy that uses in solving the problem, so we can conclude that the subject isn't able to solve the problem.

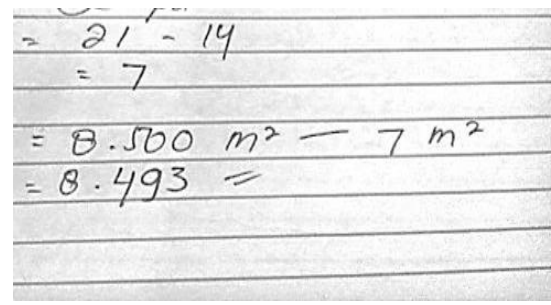

Figure 3. Strong field dependent student (SFD) problem test answer number 2

The student writes the problem formula and information that have known before, but subject incorrect understanding one of the information, on description "surface area $=8500$ ". It should be the price of grass in the meter. So from the mistake that has been made by the subject, it can be seen that students will use a strategy that is not appropriate in solving the problem that has been given. So the final answer given by the student was incorrect.

This is the extract of interviews conducted by researchers to explore the problems that exist in a student when working on number 2 , as well as knowing the extent to which students understand the problem.

$R \quad:$ "from the problem that you have read, what formula did you get from the problem?"

SFD : "what was asked is the area of the rest of the park"

$R \quad: \quad$ "why did you say that what was asked was the area of the rest of the park?"

SFD : "because the problem that exists, the information that is known is the area of the park mom"

From the interview, it appears that the student is wrong in determining the formulation of the problem. From the mistake student has done, it will affect the strategy student takes in solving problems. The possibility is subject is wrong in understanding the information contained in the 
existing problem. Based on the answers and extracts of the interview conducted by the researchers, it appears that the student determines the formulation of the problem from information that has been obtained. After finding the information and formulation of a new student, take a strategy that is considered correct by the student.

From the overall result of the answers and interviews that have been carried out by the researchers, it can conclude that SFD students tend to be wrong in finding the formulation of the problem and sometimes the subject makes a mistake in finding the information in the problem. Because of the tendency of errors if these two things resulted in the student will do a strategy that is less precise in solving the problem and result in the final answer obtained from the calculation of the student is not right.

Critical thinking of SFD subject in solving existing problems tends to be less mastering in terms of formulating problem. The formulation of the problem that finds by students greatly affects the student in planning strategies that will be used in solving existing problems. So, the mistakes made by SFD also affect the result that will be obtained by students. SFD sometimes in finding information on the problem is less able to explain it. This is in accordance with research conducted by Rifqiyana \& Susilo (2016) which states that SFD is less able to determine the facts that exist in the problem. SFD in planning and implementing strategies based on formulations that have been found by students, tended to use concepts that only remembered. So the SFD is less able to explain the strategy that has been used by the subject in solving existing problems. SFD tended not to be able to make conclusions on the existing problem. So the SFD in solving the problems tends not to complete the indicators in problemsolving and critical thinking indicators from students.

SFD subject has the same thinking as same as WFD subject. It is just SFD subject is better than WFD subject when planning and do the strategy. But SFD subject in finding the information that exists in problem tend incomplete. So the final answer that subjects given incorrectly. SFD subject explains information that subjects find out based on the subject argument. Sometimes the subject did a mistake with the wrong calculation. This is influence the final answer. Even that, the subject can solve the problem until the final answer from the problem. So it can be said that students' critical thinking in solving the problem, SFD subject is better than the WFD subject. This finding is relevant to some previous studies (Ngilawajan, 2013; Rifqiyana, 2016).

\section{CONCLUSION}

Characteristics of strong field dependent students toward critical thinking are not good at understanding the problem, in explaining the formulation and information in the problem that there is a good enough student. At the stage of making a solution plan, the student writes down what is known and asked. But the subject is less able to put forward a solution plan clearly and logically with the problem. At the stage of carrying out the solution plan, the subject carries out the plan by the plan that was previously announced. The problem-solving plan depends on the formulation of the problem found by the student because students lack an understanding of the formulation so that students are less precise in carrying out problem-solving. Students in the final stage do not re-check the answers given. Characteristics of critical thinking of weakness field dependent are that students are not good at understanding the problem given, in explaining the formulation and information that is on the problem that there is a fairly good student. At the stage of making a solution plan, students do not write down what is known and asked. Subjects are less able to put forward a clear and logical solution to the problem. At the stage of carrying 
out the solution plan, the subject carries out the plan by the plan that was previously announced. The problem-solving plan depends on the formulation of the problem found by students because students do not understand the formulation so that students are less precise in carrying out problem-solving. Students in the final stage do not re-check the answers given.

\section{REFERENCES}

Afifah, D. S. N. (2011). Pemahaman siswa SMA dalam memecahkan masalah matematika ditinjau dari perbedaan gaya kognitif (Unpublished thesis). Surabaya: Universitas Negeri Surabaya.

Albitz, R. S. (2007). The what and who of information literacy and critical thinking in higher education. Portal: Libraries and the Academy, 7(1), 97-109.

Chinien, C. A., \& Boutin, F. (1993). Cognitive Style FD/I: An important learner characteristic for educational technologists. Journal of educational technology systems, 21(4), 303-311.

Emir, S. (2013). Contributing of teacher's thinking styles to critical thinking dispositions (Istanbul-Fatih sample). Educational Sciences: Theory \& Practice., 13(1), 337-347.

Ennis, R. H. (1995). Critical thinking. New Jersey: Prentice-Hall.

Facione, P. A. (2011). Critical thinking: What it is and why it counts. Insight assessment, 2007(1), 1-23.

Facione, N. C., \& Facione, P. A. (1996). Externalizing the critical thinking in knowledge development and clinical judgment. Nursing Outlook, 44(3), 129-136.

Fithriyah, I. ., Sa'dijah, C., \& Sisworo. (2016). Analisis kemampuan berpikir kritis siswa Kelas IX-D SMPN 17 Malang. In Prosiding Konferensi Nasional Penelitian Matematika dan Pembelajarannya (pp. 580-590). Surakarta: Universitas Muhammadiyah Surakarta.

Halpern, D. F. (1998). Teaching critical thinking for transfer across domains: Disposition, skills, structure training, and metacognitive monitoring. American Psychologist, 53(4), 449-455.

Hendricson, W. D., Andrieu, S. C., Chadwick, D. G., Chmar, J. E., Cole, J. R., George, M. C., ... \& Meyerowitz, C. (2006). Educational strategies associated with development of problem-solving, critical thinking, and self-directed learning. Journal of Dental Education, 70(9), 925-936.

Huang, H. F., Ricci, F. A., \& Mnatsakanian, M. (2016). Mathematical teaching strategies: Pathways to critical thinking and metacognition. International Journal of Research in Education and Science, 2(1), 190-200.

Huang, L. Y., \& Yeh, Y. C. (2017). Meaningful gamification for journalism students to enhance their critical thinking skills. International Journal of Game-Based Learning (IJGBL), 7(2), 47-62.

Hudha, M. N., \& Batlolona, J. R. (2017). How are the physics critical thinking skills of the students taught by using inquiry-discovery through empirical and theorethical overview?. Eurasia Journal of Mathematics, Science and Technology Education, 14(2), 691-697.

Maandig, R. B., Lomibao, L. S., \& Luna, C. A. (2017). Structured Content Reading Instruction vs. Direct Instruction: Their Implication on Students' Achievement, Reading Comprehension and Critical Thinking in Mathematics. American Journal of Educational Research, 5(5), 574-578.

Mayer, R. E., \& Massa, L. J. (2003). Three facets of visual and verbal learners: Cognitive ability, cognitive style, and learning preference. Journal of Educational Psychology, 95(4), 833-846. 
International Journal on Teaching and Learning Mathematics

2018, Vol. 1, No. 1, pp. 31-38

P-ISSN: 2621-2196, E-ISSN: 2621-2196

Ngilawajan, D. A. (2013). Proses berpikir siswa SMA dalam memecahkan masalah matematika materi turunan ditinjau dari gaya kognitif field independent dan field dependent. Pedagogia, 2(1), 71-83.

Paradesa, R. (2016). Kemampuan berpikir kritis matematis mahasiswa melalui pendekatan konstruktivisme pada matakuliah matematika keuangan. Jurnal Pendidikan Matematika JPM RAFA, 1(2), 306-325.

Rasiman. (2015). Leveling of critical thinking abilities of students of mathematics education in mathematical problem. IndoMS-JME, 6(1), 40-52.

Riding, R. J., \& Sadler-Smith, E. (1997). Cognitive style and learning strategies: Some implications for training design. International Journal of training and Development, 1(3), 199-208.

Rifqiyana, L, M., \& Susilo, B. E. (2016). Analisis Kemampuan berpikir kritis siswa Kelas VIII dengan pembelajaran Model $4 \mathrm{~K}$ ditinjau dari gaya kognitif siswa. Unnes Journal of Mathematics Education, 5(1), 40-46.

Sadler-Smith, E., \& Badger, B. (1998). Cognitive style, learning and innovation. Technology Analysis \& Strategic Management, 10(2), 247-266.

Sadler-Smith, E., \& Riding, R. (1999). Cognitive style and instructional preferences. Instructional science, 27(5), 355-371.

Siew, N. M., \& Mapeala, R. (2016). The effects of problem-based learning with thinking maps on fifth graders' science critical thinking. Journal of Baltic Science Education, 15(5), 602-616.

Tascón, L., Boccia, M., Piccardi, L., \& Cimadevilla, J. M. (2017). Differences in spatial memory recognition due to cognitive style. Frontiers in pharmacology, $8,550$. 